\title{
The methodology used to deliver information literacy instruction by a select group of academic librarians: a case study
}

Information literacy instruction

\author{
Simone Julie-Ann Harrison
}

Main Library, The University of the West Indies, Mona, Jamaica, and

Mark-Jeffery O'niel Deans

Department of Library and Information Studies, The University of the West Indies, Mona, Jamaica

\begin{abstract}
Purpose - The purpose of the study is to highlight the need for academic librarians to incorporate effective methodologies in their delivery of information literacy instruction.

Design/methodology/approach - The researchers conducted a qualitative research using a case study approach. A nonprobability or purposive sampling method was employed in this research to select five participants. Semistructured interviews and observation were used to garner data from the sample.

Findings - The findings of the study revealed that the support required by distance education and face-to-face students is typically the same. An examination of the findings pointed to the fact that some students may be demotivated in information literacy instruction sessions because of an overload of information, which leads to frustration and poor performance.

Practical implications - The findings of the study highlight the need for Caribbean academic librarians to incorporate effective methodologies in their delivery of information literacy instruction and provide an analytical view of how these methodologies may impact performance, understanding and the overall work produced by both students and faculty.

Originality/value - Research on the topic specific to the Caribbean is limited; therefore, research of this nature provides useful strategies that academic librarians may use in developing stellar information literacy programs in the Caribbean to help both students and faculty members achieve excellence.
\end{abstract}

Keywords Teaching strategies, Distance education, Information literacy instructions,

Information literacy competencies

Paper type Research paper

\section{Introduction}

Academic libraries have developed programs in response to the need for information literacy, offering information literacy instruction (ILI) and providing support for students and faculty. The extent to which these programs are successful is dependent on the application of knowledge and skills of ILI and methods of delivery by librarians. The methodology used to deliver information literacy instructions by librarians and faculty is a choice that can be left to the educator (Weightman et al., 2017). However, we cannot ignore the fact that there is increased use of technology in delivering ILI. This is coupled with the empowered independence of students to use social media to seek information on their own

(c) Simone Julie-Ann Harrison and Mark-Jeffery O'niel Deans. Published in Asian Association of Open Universities Journal. Published by Emerald Publishing Limited. This article is published under the Creative Commons Attribution (CC BY 4.0) licence. Anyone may reproduce, distribute, translate and create derivative works of this article (for both commercial and non-commercial purposes), subject to full attribution to the original publication and authors. The full terms of this licence may be seen at http://creativecommons.org/licences/by/4.0/legalcode

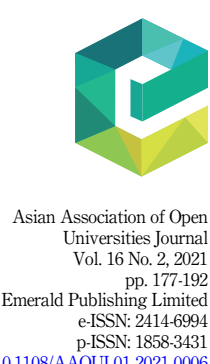

DOI 10.1108/AAOUJ-01-2021-0006
Received 26 March 2021

Revised 25 June 2021

Accepted 14 July 2021 
AAOUJ

16,2 via a plethora of websites and social media platforms (Miller, 2018). This technological proliferation has given rise to the integration of a variety of methodologies in the delivery of ILI.

Wang (2010, p. 20) suggests that in advocating for the integration of information literacy across academic curricula, "the knowledge does not exist and cannot be discovered; instead, it needs to be developed and constructed through interaction in a collaborative environment." A key factor for the integration of methodology in the delivery of ILI is to ensure that students and faculty are enabled to become information literate through the provision of effective information literacy teaching and learning opportunities (John and Chewhoma, 2015). To this extent, the delivery of content to satisfy the set of skills needed by individuals to develop lifelong learning skills and competencies inclusive of the ability to select, access, evaluate, use and communicate information effectively is achievable.

The paper provides valuable information on the kind of strategies used to deliver ILIs, particularly in support of distance education. Online feedback questions, social media tools and telecommunication applications such as Skype and zoom are mentioned as possible resources used by the librarians in instruction delivery. Consequently, a discussion on the recommended use of asynchronous and synchronous content delivery is purported by the authors.

Additionally, the paper explores the views of academic librarians on the content used to deliver ILI. The librarians interviewed are all affiliated with a world-class institution, which is located in St. Andrew, Jamaica. The institution has seven (7) main faculties within which it offers several programs at both the undergraduate and postgraduate levels. Information literacy is an integral part of the Institution's offerings as it seeks to equip its students with the skills to become productive users of information through their ability to locate, evaluate and use information effectively (Rodney-Wellington, 2007). Students are allowed access to a wide range of resources available both in the physical library and online, in various formats. Chief among the findings is that integration of methodology in the delivery of ILI is necessary to ensure pedagogical support.

\section{Literature review \\ Views of the academic librarians on the content used in delivering information literacy instruction}

There are seven key standards and associated subskills that an information literate person should develop. These include defining, identifying, accessing, evaluating, developing, communicating and using information (Swapna and Biradar, 2017; Aavarti et al., 2018). The content for developing the ability to "define," for example, should enable students to define the information on a topic; define a thesis statement and questions based on their information need as well as identify the key concepts that describe the information need and revise or modify the information need (Swapna and Biradar, 2017). Yevelson-Shorsher and Bronstein (2018, p. 5) purport that librarians believe that current information literacy programs being taught "are short and focus only on using specific sources because students are usually impatient and uninterested." This they stated is due to the information literacy program, which includes students gaining exposure to a wider range of information sources and more up-to-date information-seeking strategies, which is more comprehensive than bibliographic instruction.

Aharony and Bronstein (2013) researched academic librarians' perceptions of information literacy. They found that the librarians believed that it was their responsibility to make students understand that information literacy skills will help them in their future. The librarians engaged in designing course materials that would fit students' immediate needs, and they prescribed to the notion that students learn when they feel the need to do so. The 
librarians also aimed at getting students to be less reliant on Google and to understand the importance of critical thinking and independent learning. In Gross et al.'s (2018) study, academic librarians shared their views of the impact of the Association of College and Research Libraries (ACRL) information literacy framework for higher education on their work. The participants agreed that the Framework provided clarity in their delivery of content and that it was intellectually stimulating.

In general, the content of the information literacy curriculum is important to the effective delivery of instructional lessons. The views of librarians on the content of the ILI provide insights on issues related to content as well as give suggestions for improvements. The ACRL framework guides the development of content and has a seemingly valuable impact on those topics or aspects of information literacy to be emphasized for students to develop the necessary competency.

\section{Teaching strategies used by the select group of librarians in delivering information literacy instructions}

Tshuma and Chigada's (2018) study titled, “Analysing Information Literacy Practices at Selected Academic Libraries in Zimbabwe" highlighted the strategies used in the implementation and teaching of information literacy programs within Zimbabwean academic libraries. The strategies used, they noted, include (1) The introduction of information literacy as an accredited course; (2) the integration of information literacy with other courses; (3) information literacy as a stand-alone program; and (4) information literacy as part of orientation. Other strategies employed in the delivery of IL, as stated by the pair, included voluntary (though this is not recommended especially in the context of the academic library) and in-class tutorial for students to develop hands-on skills; a hybrid method where students engage in practical development, in class as well as via online tutorials.

Cardenas and Ramirez (2014) researched the methodologies for the teaching and learning of information literacy by two Mexican universities. The universities, namely National Autonomous University of Mexico (UNAM) and Autonomous University of San Luis Potosi (UASLP), are considered as two stellar institutions in Mexico that offer library and information degrees at both the bachelor's and the master's levels. The methodologies used by UNAM in the teaching of Information Literacy include reading, presentation, discussion, arguments, elaboration of concept maps, brochure design, posters; solving practical tasks, students as "Conference Teachers" for their classmates as well as individual and group activities using the social web. UASLP, on the other hand, engaged in the use of methodologies, such as the use of subject's sites, Google sites, initial diagnosis, teacher/ students' presentations, reading analysis and elaboration of comparison charts, time points, summary and research.

Detlor et al. (2012) investigated the advantages of using active learning strategies in the delivery of ILI. They claimed that the approaches currently in use need to be improved. Essentially, they advocated for the use of teaching strategies that encourage students to be active participants in the learning process for more successful learning outcomes. Additionally, the authors agreed that students being able to use higher-order thinking skills while being engaged in critical thinking activities (e.g. analysis, synthesis, reflection, evaluation) will help them to improve their critical thinking skills and to recognize their attitudes and values. Equally important to this discussion is Sanderson's (2018) research on the critical consideration of learning styles in the delivery of ILI. She noted that learning styles could be effective for the successful delivery of ILI through the use of diagnostic tests and encouragement to identify and tailor learning situations that are best suited for students. 
AAOUJ

16,2

\section{Challenges faced by the select group of librarians in delivering information literacy}

\section{instructions}

Information literacy skills are increasingly important to access, evaluate and use information effectively in the information society and for people to become lifelong learners. Honing these skills is especially important for students at the university level as they are required to explore and produce information independently for various aspects of their study (El Hassani, 2015). Swapna and Biradar (2017) argued that while the concept of information literacy has been embraced by many universities, it is important that initiatives are effectively promoted and executed to produce more confident and independent information seekers. Anunobi and Ukwoma (2016), in their study on information literacy in Nigerian universities, posited that the underdevelopment of information literacy programs in higher education institutions can be attributed to the attitude of key stakeholders including administrators, academics, students and libraries. They noted additionally, "the lack of essential management commitment, ignorance of what information literacy stands for, the willingness of various departments to collaborate for effective development of programs, aversion, to innovative curricula and inadequate technological infrastructure as a hindrance to the growth of effective information literacy programs." Tshuma and Chigada (2018) also highlighted the lack of support from administration and university management as a challenge to information literacy. They stated that the lack of support results in the unstructured teaching of information literacy as sessions were conducted on a one-on-one or group basis. Further to this, they claimed that university stakeholders are not amenable to the implementation of information literacy programs, which challenges the efforts of the librarians. The underlying factor they indicated causing the resistance by university stakeholders is their belief that information literacy is the responsibility of the library.

Julien et al.'s (2018) study highlighted a vast number of challenges to ILI surrounding the common themes of lack of time and lack of adequate staffing. The lack of time was related to insufficient time to show up, prepare for class, schedule and deliver all the instruction sessions. Challenges related to lack of adequate staffing include poor student-staff ratio. The authors mentioned several additional challenges, which included balancing instruction with other job duties, lack of formal training, shortage of available instruction space and technology, lack of student motivation, limited to no cooperation from faculty, lack of support from administration and no formal assessment. Several challenges are surrounding the implementation and delivery of ILI in institutions of higher education. The most prominent ones found by the researchers included lack of support from administration, lack of faculty cooperation, lack of funding, students' motivation and those related to lack of time and lack of adequate staffing (Inskip, 2017; Kavulya, 2003; Omeluzor et al., 2017; Owusu-Ansah, 2004).

\section{Methodology}

The researchers conducted a qualitative study, using a case study approach to ascertain the methodology used by a select group of academic librarians in the delivery of ILI. Hammerberg et al. (2016) in addressing when to use and judge qualitative research purport that the qualitative research method is used in answering questions about experience, meaning and perspective, which are quite common from the viewpoint of the participant. They also stated that this method of research is inflexible and unable to be counted or measured and as such, is suitable for conducting this research.

The research is descriptive as it seeks to describe the phenomenon under study and the real-life context in which it occurs (Baxter and Jack, 2008). Semistructured interviews were employed in carrying out in-depth interviews, where participants were asked to answer present open-ended questions (Jamshed, 2014). Participants were asked for permission to record their responses using a recording device. In cases where permission was not granted, 
the researchers diligently took notes of the responses. Assurance was given to participants that their names would not be mentioned in any way, to maintain anonymity. To maintain confidentiality, the researchers developed a letter with a statement of confidentiality, which was read to each participant and then signed by the researchers and the participants before the process of data collection began.

\section{Population and sampling}

A nonprobability or purposive sampling method was employed and five academic librarians were selected to participate in the study. These were librarians who have been teaching information literacy for at least 5 years. These participants adequately represented the population of interest and were able and willing to impart their knowledge (Tongco, 2005). The academic librarians were interviewed individually within the confines of the library, as the researchers sought to gather information on the methodology they employed in delivering information literacy lessons to the members of the university community. The researchers employed direct observation as a means of collecting data from the select group of academic librarians in the sample.

\section{Data collection instruments}

This research employed the use of an interview schedule and observation checklist for data collection. The interview schedule above includes four sections with a total of 13 questions that the academic librarians were asked. Their responses were recorded using a notepad or an electronic recording device, depending on their preference Table 1.

The observation checklist above comprises seventeen (17) pointers related to "Content/ Methodology used to deliver information literacy competencies lessons." These were used to guide the researchers in carrying out the observation and to corroborate the data relating to content and methodology or strategies that the academic librarians used in delivering information literacy lessons Table 2. The checklist is designed in a table format with pointers listed in individual cells.

\section{Presentation and analysis of data}

The data collected was condensed and analyzed using narrative data analysis themes according to the research questions. Hunter (2010, p. 44) claims that narrative inquiry has been influenced by some renowned philosophers, anthropologists and psychotherapists, based on the theoretical underpinning that "telling a story about oneself involves telling a story about choice and action, which have integrally moral and ethical dimensions". Kim (2015, p. 190) suggests that narrative data analysis works together to find narrative meaning in understanding human experience through stories that further "help us to better understand the human phenomena and human existence."

\section{Findings/results}

The findings presented are based on the summary of questions from the interview schedule administered to the five (5) academic librarians who are involved in the delivery of ILI. Ten (10) questions from the schedule were selected and presented along with a summary of the findings based on the responses of the participants. These questions were formulated from the three objectives of the research. Questions 4-7 covered objective 1, which was to find out the views of the academic librarians on the content used to deliver ILI. Questions 8-10 covered objective 2 , which was to ascertain the teaching strategies used by the select group of 


\section{AAOUJ 16,2}

\section{Section Data captured \\ Related questions}

1 Demographic data

2 The content of the information literacy curriculum

3 Teaching strategies used by the select group of librarians to deliver information literacy competencies lessons

$4 \quad$ Challenges faced by the select group of librarians in delivering information literacy instruction
(1) What is the academic level of students that you teach information literacy instruction?

(2) How long have you been delivering information literacy instruction in the context of the academic library?

(3) On average, how many information literacy instruction sessions are you required to teach in an academic year?

(1) What aspects of the information literacy curriculum address the required competencies stipulated by the institution?

(2) What level of input, if any is faculty allowed to make in the development of content for information literacy instruction?

(3) What are some of the main criteria considered in content revision by academic librarians?

(4) How does the curriculum cater to the various needs of the students in the various disciplines?

(1) What are the teaching strategies used to deliver information literacy instruction?

(2) What kind of support does the library offer to both distance education and face-to-face students?

(3) How is students' information literacy competencies assessed?

(1) What aspects of delivering information literacy instruction are the most challenging to you?

(2) What areas of improvement if any would you suggest in enhancing the delivery strategies used in information literacy instruction?

(3) How adequate are the instructional sessions in delivery the information literacy competencies?
Table 1.

The interview schedule librarians to deliver ILIs. Finally, questions 11-13 covered objective 3, which was to identify the challenges faced by the select group of librarians in delivering ILI.

A summary of the responses of the participants as well as data gathered from the observations done is included.

Q4. What aspects of the information literacy curriculum address the required competencies stipulated by the institution?

Responses included:

The University wants graduates who are lifelong learners with the ability to be critical thinkers ... The IL curriculum responds to that

I think all aspects of the curriculum addresses what the University requires students to know.

Information literacy lessons in the faculty of law are more specific to the discipline ... Although tailored so that students can develop the skills to apply within this area of study, the skills learned can be transferred to other areas. 


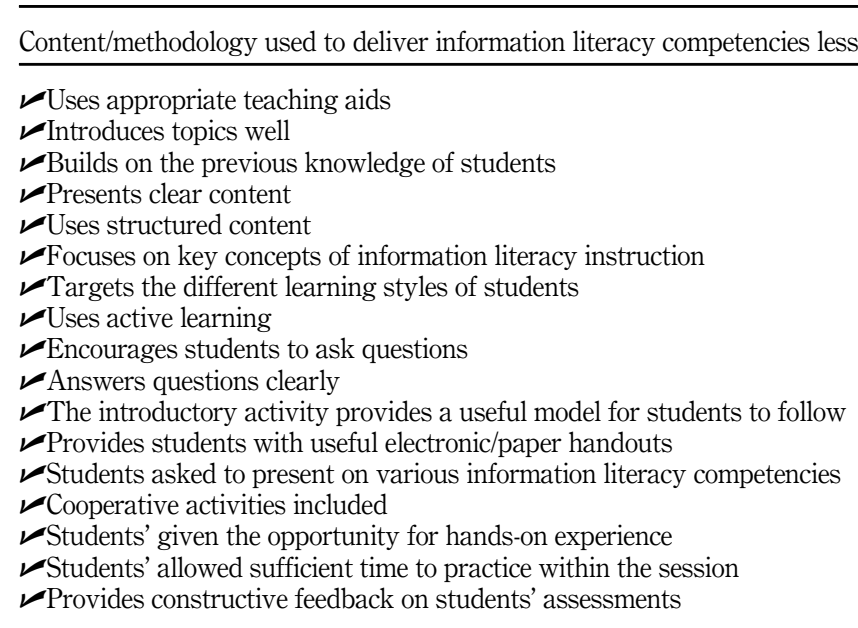

Comments
Information literacy instruction

183
Table 2.

Observation checklist

All the participants supported the view that all aspects of the information literacy curriculum addressed the required competencies stipulated by the institution. It was observed that lessons focused on the key concepts of ILI and that students were given the opportunity for hands-on experience. However, in most of the observation sessions, students were asked to present various information literacy competencies.

Q5. What level of input, if any, is the faculty allowed to make in the development of content for information literacy instruction?

Responses included:

Faculty is allowed to make as much input as they want to as long as they do not attempt to derail the agenda of academic librarians in their delivery of IL skills.

Faculty provides us with the topics that they want us to teach the students, usually for an upcoming assignment. Their input is welcome and they are allowed to give as much input as possible.

They are given a very high level of input. We customize the lessons to suit their requests.

Faculty dictates the content/areas that academic librarians should teach students (50/50 input). For foundations courses, faculty will also inform the library of the areas that they want students to learn.

All the participants conceded that the faculty is allowed to make a significant input in the development of content for ILI. The majority of the participants stated that faculty usually provides the content areas and skills they want to be emphasized in an information literacy lesson. This they noted is allowed for both foundations courses and those offered within specific disciplines in which faculty may make special requests for lessons. One participant claimed that despite faculty being allowed to make an input, some are unwilling and thus, it is difficult to collaborate relationship with them.

Q6. What are some of the main criteria considered in content revision by academic librarians? 


\section{AAOUJ}

16,2

\section{4}

\section{Responses include:}

Development (changes/adjustments) in the law, principles for the consideration in new search strategies to be taught, change in the database interface, different approaches

Of course, the requests made by faculty are paramount in determining what to teach. However, from any customized session we want our students to be empowered to use keywords, synonyms and related terms to locate sources, to evaluate scholarly sources in all formats, to evaluate, cite and reference these sources accurately to avoid plagiarism.

Trends, what's new, innovative and standards. It may also be based on discussions among librarians on different areas that they see the need to change.

The participants' responses indicated that content revision is considered by academic librarians. Their responses, however, were different in terms of particular criteria considered in making adjustments to the content. Some of the criteria they mentioned include the relevance of content, new trends, changes in the law, new search strategies and the suitability of allotted time for the delivery of information literacy lesson. One participant noted with particular reference to the foundation courses that changes have been made over the years to reduce the content of the PowerPoint lesson to keep within the $2 \mathrm{~h}$ allotted time and to ensure that key concepts are taught.

Q7. How does the curriculum cater to the various needs of the students in the different disciplines?

Responses included:

Each discipline has its own peculiarity; therefore, librarians must develop teaching strategies to relate to that. What is included in the curriculum of IL for disciplines will be dependent on the specific areas of the discipline.

The disciplines have different information resources and different avenues through which they can be located. Therefore, it requires subject knowledge so if you are searching the sciences, Web of Science is a particular database or for Medicine, Medline, Ovid. Librarians can direct the students accordingly.

We address the various needs of students in the sense that the lessons are customized and we work with faculty to address the needs of students. We would then modify each lesson with the faulty in mind. For example, Education may want us to teach their students the skills in APA citation but Faculty of Science and Technology may require ACS.

The participants' responses supported the question as they noted that the information imparted to students is dependent on the needs in the specific disciplines. One participant explained that each discipline has different information resources and different ways of finding them. Therefore, subject knowledge is required to search within the different disciplines. They provided examples of databases, such as Medline and Academic Search Complete that are used in different disciplines. Also, different citation styles, including APA and ACS, are also used in different disciplines. These examples were used to indicate how they cater to students in the different disciplines.

Q8. What are the teaching strategies used to deliver ILI?

Responses included:

There are the one-on-one sessions, and yes I do have small group interactions sometimes. Maybe a group of friends from a group may ask me to go through something with them. Not so much social media though even though we do have a Twitter account. Yes, there is Ask-a-Librarian virtual reference and chat and email, orientation and lots of question and answer. Also, use of libguides especially to follow up on what is done in class. 
Sometimes again depending on the group, there is an app that I use sometimes. It's more of a . . I'm just testing it to see how it would work ... It's called Nearpod and this is to get students interacting more rather than just me talking at them for them to have the information on their individual screens so they can interact.

Our thesis consultation sessions with postgraduates allow us to teach them one-on-one IL skills and beyond, Literature Review, proposal writing and so on. We have online feedback questions on topics taught to test their understanding of lessons taught.

The participants stated that the general strategies used in delivering ILI include one-on-one sessions, small group presentations, library orientation, assignments and handouts as well as question and answer sessions. Other strategies mentioned include ask-a-librarian virtual reference, chat, email, worksheet, orientation, collaborative activities, question and answer and the use of libguides to follow-up on what is done in class. One participant highlighted the use of a student-centered application called Nearpod, which promotes students' learning and participation through interaction. The participant explained that students can use their devices to access the application and view information and the librarian can ask them questions. As some students are shy, the application allows them to be active participants though they respond using aliases.

Q9. What kind of support does the library offer to both distance education and face-toface students?

Responses included:

... liaison librarians to give support ... They are equipped to deal with Skype queries, they have zoom meetings and they apply the same kind of technique used in a face-to-face session with distance students. Face-to-face students can talk to librarians on Ask-a-Librarian, call or send an email.

Distance students are given support through the use of videos uploaded online and real-time support through virtual reference software, such as Kayako through the week and weekend. They can also contact librarians via the telephone or by email. Face-to-face students are supported through the inhouse reference librarian service.

All the participants held the view that the library offers support to both distance and face-toface students. One participant highlighted that distance education students are required to physically attend library orientation, after which the library provides a live online session focusing on evidence-based medicine. The participants noted that some of the support sessions were a mix of face-to-face and online sessions via a video-conferencing application. Distance education students are given support through the use of videos uploaded online, through Kayako and other virtual reference software, such as Skype and Zoom. In the case of face-to face students, reference librarians are available in the library during scheduled hours for one-on-one or group consultations. Face-to-face students also get support from librarians via the ask-a-librarian virtual service. The participants pointed out essentially that both faceto-face and distance education students receive support from them via email, chat and telephone calls. They stated that students usually make contact with them at their point of need when assistance is most required in completing a task or when they are unable to locate information or resources. The queries made by face-to-face students, they asserted, are no different from those received from distance education students.

Q10. How are students' information literacy competencies assessed?

Responses included:

This is an area that for me personally I need to develop some more. At present I just do a casual question and answer on the spot in the class and give in class activities.

\section{Information literacy instruction}


AAOUJ

16,2

\section{6}

Assessment is an area that needs improvement. A type of assessment is done in foundation sessions where students are asked to complete a 5 questions online survey.

An online quiz is given at the end of the session and students are encouraged to complete it. From that the MILU is able to see what they learned from the session also to get their feedback on different aspects of the session.

This is a work in progress, but we use an electronic quiz to assess them. We are perfecting this and hope to apply to all sessions, including online lessons.

No formal instruments used in assessment. First-year legal information resources students are given 4 assignments and must demonstrate skills and knowledge in completing them.

Most of the participants made mention of an online survey that students are asked to complete at the end of an information literacy session. They noted that the survey tests what students learned on the different topics that were covered. One participant explained that through the survey, librarians found out that some students still did not grasp key competencies, such as keyword searching, brainstorming and Boolean logic. An open-ended question in the survey asked students to give feedback on how helpful the session was, the presenter and the room the session was held in. Most of the participants mentioned that assessment is an area that needs improvement. One participant's response was more personal as it highlighted that the assessment given to students in information literacy sessions was informal and done along with in-class activities. Another participant noted that students are not given formal assessment within a particular discipline. They are, however, given four assignments in which they must demonstrate in their submission, the skills and knowledge of the information literacy course taught to them. Students are also required to do in-class presentations on given topics and use the resources in the physical library to locate resources. This, the participant noted is used to identify students' grasp of the skills. If students still need help, thereafter, faculty will request librarians to reteach the lesson as the development of IL skills is important to the profession.

Q11. What aspects of delivering ILI are the most challenging to you?

Responses included:

Problems with the IT infrastructure such as the Wi-Fi maybe not working and unsuitable spaces because a long room with you standing at the front and maybe the PA system is not working or you maybe do not know how to set it up.

There are many challenges, however, the two that are major include faculty engagement/faculty collaboration as they are the ones who have to acquiesce (accept/allow) for librarians to come into the sessions.

Students' attention span as while I am teaching sometimes, I find that they tend to be browsing social network sites and that creates a distraction. I do not find that students are truly interested in the IL session.

Physical resources (a dedicated space for IL) - this affects the delivery of lessons in terms of time for setup Time in relation to the PowerPoint lesson.

All the participants stated that they have faced challenges in delivering ILI. Common challenges they all pointed out include the lack of resources, problems with the Wi-Fi, lack of dedicated spaces, student engagement, too much to teach in one session, lack of time to be creative, limited time for the delivery of lessons and some librarians not being trained teachers.

Q12. What areas of improvement if any would you suggest in enhancing the delivery strategies used in ILI? 
Responses included:

This is more long term and that has to do with the spaces and the facilities that we have. We need to have dedicated spaces for that and more frequent workshops for $\mathrm{IL}$ presenters.

The framework worldwide, people are still learning to use it and apply it and so my kind of thrust now would be to try and learn more about using it in new exercises and using it in our cultural context.

To award students points towards their grades from the quiz that they are required to do at the end of the IL session.

Teaching maybe 2-3 shorter lessons to students rather than a long 2-h session. Providing assessment and immediate feedback for students to enhance their learning experience.

The participants' responses indicated that there are areas that need improvement. They suggested that improvements should include the continuous training of librarians, incorporating the cultural context in teaching lessons, more dedicated library spaces, awarding students points upon their completion of information literacy lesson, added teaching hours over a longer period, assessment with immediate feedback, lessons in electronic form that can substitute for face-to-face lessons, make lesson PowerPoint available to students, more effective teaching strategies and change in the leadership of ILI.

Q13. How adequate are the instructional sessions in delivering the information literacy competencies?

Responses included:

I think we are trying to do too much in the time that we have and this is mostly with the first years that we have. If we could space it out depending on faculty because they would have to determine that they have this amount of time in their curriculum for it.

I'd like to see students at least twice for the semester but there are very few courses right now where we get that kind of interaction.

If you are thinking in terms of length of time allotted for training sessions is adequate then I would prefer $2-1 \frac{1}{2}$ or $3-1$ hour sessions to teach the skills better than a 1 shot 2 -h session.

Adequacy would have to be determined by an impact assessment. Usually in Law, lecturers will request librarians to reteach topics if they find that students are not proficient in utilizing resources, failing courses, etc.

All the participants noted that the time allotted for the delivery of information literacy competencies is inadequate. They shared the general view that: too much was being done in the 2 -h session, adding more teaching hours would give students greater exposure to information literacy, which would better help in assessing the impact of the lessons on them. One participant highlighted an intervention method used by one discipline, in which, the librarian is asked to reteach a session if it is identified that students did not grasp the concepts of the lesson taught or if they are having challenges with assignments given by faculty in which they were expected to use skills from ILI to complete.

\section{Discussion}

Three main themes emerged from the findings of the research, which were reflective of the objectives of the research. The researchers identified these as content used in delivering ILI, strategies used in the information literacy program and support to distance education students and face-to-face students. These will be discussed briefly.

\section{Information literacy instruction}




\section{AAOUJ Content used in delivering information literacy instruction}

16,2

It was evident from the findings that the participants in the research utilized the ACRL framework as a guide for the development of content taught. The ACRL framework has been very effective in making instructional lessons more conversational interactive and hands-on, allowing students the opportunity to benefit from both implicit and explicit instructions (Hendrigan et al., 2020; Latham et al., 2019). In support of this, Hofer et al. (2013) explain that the constant revision of the standards is important, especially in a time of post-Google information landscape where culturally, citizens are impacted by a myriad of emerging technologies and unprecedented modes of information access. Ultimately, the ACRL framework can be used in the teaching of information literacy and as well as in standards revision. Furthermore, Hofer et al. (2013) posited that the need for a framework is important and that the ALA/ACRL standards provide a common language for the content of information literacy lessons.

\section{Strategies used in the information literacy program}

The findings indicated that the participants employed several strategies that were effective in their view when delivering ILI to students within the online and face-to-face delivery modes. This is consistent with research done by Shamsaee et al. (2021) showing the effectiveness of integrating several approaches such as virtual (online and offline) and face-to-face education when teaching information literacy. It is also supported by research done by Lwehabura (2008), which highlighted those librarians used orientation, hands-on practice, webpages, seminars and leaflets in their provision of ILI.

\section{Support to distance education students and face-to face students}

There was a general consensus among the participants that the library offers support to both distance and face-to-face students and that there is the need to continuously revise the curriculum to meet both modern and international standards. Again, "Constant revision of the curriculum of the programme is necessary to reflect innovations and skills for information retrieval and dissemination, especially as it relates to the introduction of modern Information and Communication Technology (ICT) facilities" (Anunobi and Ukwoma, 2016, p. 348). The authors further recognized that the lack of adequate Internet resources is seen as a factor that could limit successful outcomes in the information literacy program. This was also an issue highlighted in the findings of the study.

\section{Conclusion}

A vast amount of information is available on the topic of information literacy in higher education with specific reference to its teaching and the methodologies used by various universities in its delivery. However, research on the topic, specific to the Caribbean, is limited. El Hassani (2005), in examining the role of information literacy in higher education, reasoned that the change in the information landscape brought about by the Internet now requires persons to develop new skills for searching and using information. He further stated that these skills are taught under the concept of information literacy, which enables individuals to identify, access, organize and synthesize information for use in a meaningful way. Of importance to this study are the methodologies used by a select group of academic librarians in the delivery of ILI. The findings of the research support the idea purported by Sural and Dedebali (2018) that in building the digital capabilities of their students, information literacy teachers can continuously improve themselves. They can critically assess the need to use the most appropriate teaching instrument for ILIs with their students. 
These scholars can use various teaching approaches and methodologies, enhanced by new technologies and different sources to accomplish the task.

It can also be argued based on the findings that information literacy is an important component of the education that students at the higher education level should receive. They need the abilities and understandings promoted by the ACRL framework for higher education to function effectively in the current information environment. As technology changes, students will need to be able to utilize the functionalities of the devices and know how to access the growing wealth of information available on different platforms. They will also need to be able to contribute to the creation of content and use information effectively in making informed decisions for the benefit of themselves and others.

\section{Recommendations}

In keeping with the findings emanating from the research, some gaps identified and suggestions from participants, the following recommendations are being made with a view of enhancing the delivery and assessment of ILI at the institution. There exists a need for academic librarians to acquire and utilize a variety of instructional techniques in keeping with the nature of the content being presented and the performance standards required by the institution. In this way, all librarians will be familiar with the strategies to be engaged when delivering specific ILI content areas. For librarians to use different strategies, it may be necessary to organize capacity-building sessions to empower those delivering the content. This will be necessary as new approaches to ILI are adapted for program enrichment. Dedicated time slots should be made available to allow librarians to deliver ILI lessons. This will ensure stability in the delivery of content.

Based on the fact that faculty engagement/faculty collaboration was identified as a challenge in the delivery of information literacy, it is being recommended that faculty and librarian collaboration be considered as a critical component of the methodology used in supporting student learning. As postulated by Brady and Malik (2018), information literacy skills development can be heightened by librarians and faculty using a shared vocabulary to engage in meaningful conversation about the planning and implementation of course assignments [and] the critical examination of various paths to information literacy through the engagement of librarian and faculty.

The research highlighted the fact that "distance students are given support through the use of videos uploaded online and real-time support through virtual reference software, and that face-to-face students are supported through the in-house reference librarian service." It is being recommended that both asynchronous and synchronous online information literacy sessions be embedded into the structured delivery sessions for both distance and face-to-face students. Thus, increasing the flexibility of the program and allowing multiple modes of delivery of the course. According to Toit (2018), "E-learning provides flexibility and students can follow online modules in their own time and at their own pace."

Finally, based on the fact that the findings revealed that some students did not seem to regard ILI as an essential part of their program, policy steps should therefore be taken to make ILI compulsory. This could be achieved by allocating credits to the program.

\section{References}

Aavarti, S.R.M.T., Chaudhary, P., Asjola, V. and Muduli, P.K. (2018), "The information literacy competency standards for 21st century higher education", pp. 1-9, available at: https://www. researchgate.net/publication/348871341_The_Information_Literacy_Competency_Standards_ for_21st_Century_Higher_Education. 
AAOUJ 16,2

Aharony, N. and Bronstein, J. (2013), "Academic librarians' perceptions on information literacy: the Israeli perspective”, Libraries and the Academy, Vol. 14 No. 1, pp. 103-119, available at: www. researchgate.net/publication/265762339_Academic_Librarians'_Perceptions_on_Information_ Literacy_The_Israeli_Perspective.

Anunobi, C. and Ukwoma, S. (2016), "Information literacy in Nigerian universities: trends, challenges and opportunities", New Library World, Vol. 117 Nos 5/6, available at: www.emerald.com/ insight/content/doi/10.1108/NLW-10-2015-0078/full/html.

Baxter, P. and Jack, S. (2008), "Qualitative case study methodology: study design and implementation for novice researchers", The Qualitative Report, Vol. 13 No. 4, pp. 544-559, available at: www.// nsuworks.nova.edu/cgi/viewcontent.cgi? article $=1573 \&$ context $=$ tqr.

Brady, L.L. and Malik, M. (2018), "Science, story, and structure: framing the conversation for psychology faculty and librarian information literacy collaboration", Teaching of Psychology, Vol. 46 No. 1, pp. 64-71, doi: 10.1177/0098628318816155.

Cardenas, C.M. and Ramírez, V.S. (2014), "Methodologies for the teaching and learning of information literacy in two Mexican universities", Qualitative and Quantitative Methods in Libraries, Vol. 4, pp. 821-828, available at: www.qqml.net/papers/December_2014_Issue/344QQML_Journal_ 2014_CardenasandRamirez_Dec_821-828.pdf.

Detlor, B., Booker, L., Serenko, A. and Heidi, J. (2012), "Student perception of information Literacy instruction: the importance of active learning”, Education for Information, Vol. 29, pp. 147-161, doi: 10.3233/EFI-2012-0924.

El Hassani, A. (2015), "The role of information literacy in higher education: an initiative at $\mathrm{Al}$ Akhawayn University in Morocco", Nordic Journal of Information Literacy in Higher Education, Vol. 7 No. 1, pp. 32-37, doi: 10.15845/noril.v7i1.229.

Gross, M., Latham, D. and Heidi, J. (2018), "What the framework means to me: attitudes of academic librarians toward the ACRL framework for information literacy for higher education”, Library and Information Science Research, Vol. 40, pp. 262-268, available at: www.sciencedirect.com/ science/article/abs/pii/S0740818818301567?via\%3Dihub.

Hammerberg, K., Kirkman, M. and Lacey, S.D. (2016), "Qualitative research methods: when to use them and how to judge them”, Human Reproduction, Vol. 31 No. 3, pp. 498-501, doi: 10.1093/ humrep/dev334.

Hendrigan, H., Mukunda, K. and Cukierman, D. (2020), "A case study and call to action: incorporating the ACRL framework for information literacy in undergraduate CS courses", Proceedings of the 2020 ACM Conference on Innovation and Technology in Computer Science Education. doi: 10. 1145/3341525.3387401.

Hofer, A., Brunetti, K. and Townsend, L. (2013), "A threshold concepts approach to standards revision”, Communications in Information Literacy, Vol. 7 No. 2, pp. 108-113, available at: https://files.eric.ed.gov/fulltext/EJ1089070.pdf (accessed 2 June 2019).

Hunter, S.V. (2010), “Analysing and representing narrative data: the long and winding road”, Current Narratives, Vol. 1 No. 2, pp. 44-54, available at: www://ro.uow.edu.au/cgi/viewcontent.cgi? article $=1011 \&$ context $=$ currentnarratives.

Inskip, C. (2017), "Practitioner and LIS student perspectives on information literacy for librarians", ACRL, pp. 486-497, available at: www.ala.org/acrl/sites/ala.org.acrl/files/content/conferences/ confsandpreconfs/2017/PractitionerandLISStudentPerspectivesonInformationLit.pdf.

Jamshed, S. (2014), "Qualitative research method-interviewing and observation", Journal of Basic And Clinical Pharmacy, Vol. 5 No. 4, pp. 87-88, doi: 10.4103/0976-105.141942.

John, H.C. and Chewhoma, E. (2015), "Information literacy education among faculty and students: the role of Laz otti memorial library, Babcock University, Nigeria", Journal of Information and Knowledge Management, Vol. 5 No. 5, pp. 24-30, available at: www.researchgate.net/publication/ 320024474_Information_Literacy_Education_among_Faculty_and_Students_The_Role_of_ Laz_Otti_Memorial_Library_Babcock_University_Nigeria. 
Julien, H., Gross, M. and Latham, D. (2018), "Survey of information literacy instructional practices in U.S. academic libraries", College and Research Libraries, Vol. 79 No. 2, doi: 10.5860/crl.79.2.179.

Kavulya and Joseph, M. (2003), "Challenges facing information literacy efforts in Kenya: a case study of selected university libraries in Kenya", Library Management, Vol. 24 Nos 4/5, pp. 216-222, doi: 10.1108/01435120310475301.

Kim, J. (2015), Understanding Narrative Inquiry: The Crafting and Analysis of Stories as Research, Sage Publication, Los Angeles.

Latham, D., Gross, M. and Julien, H. (2019), "Implementing the ACRL framework: reflections from the field", College and Research Libraries, Vol. 80 No. 3, pp. 386-400, doi: 10.5860/crl.80.3.386.

Lwehabura and Mugyabuso, J.F. (2008), "Information literacy delivery in Tanzanian universities: an examination of its effectiveness", African Journal of Library, Archives and Information Science, Vol. 18 No. 2, pp. 157-168, available at: http://citeseerx.ist.psu.edu/viewdoc/download?doi=10.1. $1.926 .364 \&$ rep $=$ rep1\&type $=$ pdf.

Miller, R.E. (2018), "Information literacy and instruction: reference consultations and student success outcomes”, Reference and User Services Quarterly, Vol. 58 No. 1, pp. 16-21, available at: https:// journals.ala.org/index.php/rusq/article/view/6836.

Omeluzor, S.U., Akibu, A.A., Dika, S.I. and Ukangwa, C.C. (2017), "Methods, effects and challenges of library instruction in academic libraries", Library Philosophy and Practice, available at: digitalcommons.unl.edu/cgi/viewcontent.cgi?article $=4109 \&$ context $=$ libphilprac.

Owusu-Ansah, E.K. (2004), "Information literacy and higher education: placing the academic library in the center of a comprehensive solution”, The Journal of Academic Librarianship, Vol. 30 No. 1, pp. 3-16, available at: www.sciencedirect.com/science/article/abs/pii/S0099133303001356.

Rodney-Wellington, K. (2007), The Impact of Information Literacy Skills Instructions on Grade Six Students' Information-Seeking Activities: An Experimental Study, Thesis, University of the West Indies.

Sanderson, H. (2018), "Using learning styles in information: critical considerations for librarians", The Journal of Academic Librarianship, Vol. 37 No. 5, pp. 376-385, doi: 10.1016/j.acalib.2011.06.002.

Shamsaee, M., Mangolian shahrbabaki, P., Ahmadian, L., Farokhzadian, J. and Fatehi, F. (2021), "Assessing the effect of virtual education on information literacy competency for evidencebased practice among the undergraduate nursing students", BMC Medical Informatics and Decision Making, Vol. 21 No. 1, doi: 10.1186/s12911-021-01418-9.

Sural, S. and Dedebali, N.C. (2018), "A study of curriculum literacy and information literacy levels of teacher candidates in department of social sciences education", European Journal of Educational Research, Vol. 7 No. 2, pp. 301-315, doi: 10.12973/eu-jer.7.2.303.

Swapna, G. and Biradar, B.S. (2017), "Information literacy model for higher education institutions in india", International Journal of Digital Library Services, Vol. 7 No. 3, pp. 31-50, available at: www.ijodls.in/uploads/3/6/0/3/3603729/4ijodls3717.pdf.

Toit, E. (2018), "Using technology to teach students information literacy skills: an online module for firstyear students at the University of Johannesburg (UJ)", Proceedings of the IATUL Conferences, Paper 1, available at: https://docs.lib.purdue.edu/iatul/2018/infolit/1.

Tongco, D.C. (2005), "Purposive sampling as a tool for informant selection", Ethnobotany Journal, pp. 147-158, available at: www.ethnobotanyjournal.org/vol5/11547-3465-05-147.pdf.

Tshuma, T. and Chigada, J. (2018), "Analysing information literacy practices at selected academic libraries in Zimbabwe", South African Journal of Information Management, Vol. 20 No. 1, pp. 1-7, available at: www.scielo.org.za/pdf/sajim/v20n1/16.pdf.

Wang, X. (2010), Integrating Information into Higher Education Curricula: An IL Curricular Integration Model, Dissertation, Queensland University of Technology.

Weightman, A.L., Farnell, D.J., Morris, D., Strange, H. and Hallam, G. (2017), “A systematic review of information literacy programs in higher education: effects of face-to-face, online, and blended

\section{Information literacy instruction}


AAOUJ

16,2

192 formats on student skills and views", Evidence Based Library and Information Practice, Vol. 12 No. 3, p. 20, doi: 10.18438/b86w90.

Yevelson-Shorsher, A. and Bronstein, J. (2018), "Three perspectives on information literacy in academic: talking to librarians, faculty and students", College and Research Libraries, Vol. 79 No. 4, pp. 1-26, available at: crl.acrl.org/index.php/crl/article/view/16728/18670.

\section{Corresponding author}

Mark-Jeffery O’niel Deans can be contacted at: markjeffery.deans@uwimona.edu.jm

For instructions on how to order reprints of this article, please visit our website: www.emeraldgrouppublishing.com/licensing/reprints.htm Or contact us for further details: permissions@emeraldinsight.com 